\title{
Management Skills as Determinant for Selecting Management Model Among Sports Managers in Kwara State, Nigeria
}

\section{Ibraheem Musa Oluwatoyin ${ }^{1 *}$, Abdulraheem Yinusa Owolabi², Aina Gbemisola Michael $^{3}$}

${ }^{*}{ }^{23}$ Departmen of Human Kinetic Education, University of Ilorin, Nigeria

\author{
Article History: \\ Received: 2 June 2021 \\ Accepted: 28 September 2021 \\ Published: 1 October 2021
}

\section{Keywords:}

Sports, Managers

Effectiveness, Management Skills, Management Model

\begin{abstract}
Knowledge, understanding and displaying good management skills will help sports managers of the sports organization to position the teams and clubs. Descriptive correlation study carried out using a survey method for this study. Purposive sampling technique was used to select 85 sports managers of the sports organization. Data were collected using self-developed questionnaire as an instrument. The entire questionnaire yielded a reliability value of 0.77 r. Data were analysed using multiple linear Regression at the 0.05 alpha levels.The findings show significant multiple correlations. The regression indicated that the management skills was a good contributor for the selection of management model $(\mathrm{F}(4,95)=2.267, \mathrm{P}<$ .000). Based on the findings of this study, the researcher concluded that management skills contribute to the selection of the management model. Recomendation on government and stakeholder in the state should organize seminar, workshop and training for sports managers of the sports organizations in Kwara state for them to have knowledge on management skills which is crucial to their job.
\end{abstract}

\section{How To Cite:}

Oluwatoyin, I. M., Owolabi, A. Y \& Michael, A. G. (2021). Management Skills as Determinant for Selecting Management Model Among Sports Managers in Kwara State, Nigeria. Indonesian Journal of Sport Management, 1(2), 101-108. https://doi.org/10.31949/ijsm.v1i1.1112

Corresponding author: Ibraheem Musa Oluwatoyin, Department of Human Kinetic Email: ibramus20@gmail.com 


\section{INTRODUCTION}

The choice of management skills to be adopted by the organization is been determined by the executives with regards to the objectives motivate effort, coordinate activities and allocation of avoidable resource. The executive chooses the management model to be used to run the organization, understand the principle of operation and the behaviours in the organization and finally the executives made choices on the appropriate management model to use on a host circumstantial and competitive factors. Goodarzi (2012) submitted that the structures of management models reveal the new styles have the most influences among leadership with regard to adapting to changes and developments in organizations.

In the new hastily altering economy, stimulated sports activities manager to have turn out to be the sports organization's most valuable and productive resource. This is in line with Forghani's (2015) submissin that sports organizations concerned in sports development are no exception; they additionally want efficient managers and leaders. Adopting unique types of management styles, managers facilitate the success of goals, enhance the experience of happiness and job pride of the employee, expand initiatives and eventually assist the inner organizational technique and to obtain organizational desires and consequently enlarge organizational effectiveness. Simulation scenarios, reflective exercises, and role-playing may be beneficial to facilitate the desire of optimistic warfare management styles (Nazari, 2017).

The sports managers repository of understanding is central to sports organization's aggressive gain to the improvement and execution of strategies, particularly in today's fast-paced, more perplexing world, where pinnacle management alone can no longer guarantee firm's competitiveness. Awareness of management is crucial for sports manager to better manipulate the affairs and assigned responsibilities considering the fact that management is the most enormous and influential elements in the improvement of sports and attainment of the goal. Sports management is the scientific management tendencies which are explained by means of benefiting from the frameworks of management science (Naderian 2008). At all levels, corporations want suitable efficaciously directed management skills towards attaining noted objectives. Gabriel (2014) cited international efforts being made to educate specialized and dedicated sports managers. Sports organizations want capable and tremendous sports managers. Seyedinejat (2014) lamented that; prioritization of managerial skills is one of the major challenges in senior management, most especially in sports organizations.

Effectiveness and efficient management of sports organizations, sports managers want extraordinary skills in technical skills, human skills, perceptual abilities and political skills. The necessity for the executive to have knowledge, vision, effectiveness and efficient management via perceptual, human, technical and political (Afshari, Honari, Ghafouri 2010). Technical skill is a skill that involves the knowledge and capacities to perform specialized tasks associated to a particular area and the ability to practice knowledge, technique and approach of the potential required to function the task thru experience, education and training. Human skills are essential for sports organizations to make sure they have excellent personnel to attain their strategic objectives, this human skill is the judgment required to work with people, alongside with awareness of encouragement techniques and use of an 
effective management model. Perceptual skill is the method through which persons select, prepare and interpret the enter from their senses to give which means and order to the world around them. Political talent refers to the capability to effectively understand others in the workplace and hire such understanding to have an effect on others and to take measures to promote organizational or personal desires (Fani, 2014). It used to be revealed by way of Harris, Harris, \& Harvey (2007) that organizational politics can cause members of the organization to experience a superb deal of uncertainty and ambiguity because they do not understand what actions will be rewarded, punished, or even recognized. Productivity in-game organizations can be hampered by using organizational politics. Zellars and Fiorito (1999) pointed out, organizational effectiveness is decreased as an end result of organizational politics. Respondents in a study carried out by Ram and Prabhaker (2010) reported that organizational politics adversely influence involvement at the workplace and can dampen the motivation degree to an outstanding extent.

For the purpose of improving the efficiency and effectiveness of sports organizations in Kwara state, it is essential for sports managers of any sports organizations to contain some activities that correspond to their efficiency and positive management of sport organizations with intention of enhancing technical skill, perceptual skills, human abilities and political skill which assist them to pick out a management model that will be suitable for their sports organization. Sports managers who foster precise management skills are in a position to propel the sports organization's mission.

Sports managers use management skills for positive and efficient management of sports organization. Sports manager who lack management skills usually have issues like develop unclear processes, poor documentation and inability to share sports organization knowledge, outline the scope and objectives of any information management initiatives, create a sports organisation culture of information sharing between Athletes and management, set clear goals and techniques to assist in making use of the collective understanding (otherwise, it will be of no use to the sports organization), reflect on consideration on budget, strategy and training needs for any new information management system, consider trade management techniques for introducing new information management practices. The researcher observed that majority of sports managers in Kwara state most especial those appointed by state and local government have little or no management skills because the majority of them are not expert in the area of sports management. This has resulted in poor management of sports councils in the state and local government, and this has also led to the terrible overall performance of sports teams/ clubs in the state and local government. It is on this note research work was carried out to find out if management skills will determine the selection of management model among sports managers in Kwara state.

\section{METHOD}

A descriptive correlation study carried out using a survey method for this study. The population for this comprised 85 managers of sports organizations include all managers of sports organizations in Kwara state, Kwara state sports activities council, sports activities clubs, physical education managers, sports directors at the greater organization in Kwara state, all nearby authorities sports directors. Eighty- 
five (85) sports manager and sports activities directors have been purposively chosen for this study. A self-developed questionnaire was the instrument for data collection and was validated by three experts. Test-retest method of reliability was adopted whereby 20 copies of the questionnaire was administered on sports managers in Oyo State, twice between the interval of two weeks and results of the two administered were correlated using PPMC and $0.77 \mathrm{r}$ was obtained. The questionnaire was administered with the help of three trained research assistants. The data collected was analysed using Multiple Linear Regression at .05 alpha level.

\section{RESULT AND DISCUSSION}

\section{Result}

Table 1. Model Summary of Multiple Regression for the contribution of Management Skills to the selection of Management Model among Sport Managers

\begin{tabular}{|c|c|c|c|c|c|c|c|c|}
\hline & & & & Std. error of & ANOV & & & \\
\hline Models & $\mathbf{R}$ & $\mathbf{R}^{2}$ & $\begin{array}{l}\text { Adjustea } \\
\mathbf{R}^{2}\end{array}$ & $\begin{array}{l}\text { the Estimate } \\
\text { (SEE) }\end{array}$ & $\mathbf{F}$ & df1 & df2 & Sig. \\
\hline Management skills & .295 & .087 & .049 & .935 & 2.267 & 4 & 95 & $.000 *$ \\
\hline
\end{tabular}

The table above revealed the model summary of multiple linear regression analysis. In the model, the Managements skills (perceptual management skill, Technical, Human skills and Political) was used as a contributor to the selection of management model among sports manager. The model shows significant multiple correlations. R .295. The model indicates that this variable account for $8.7 \%$ of the variance in Management skills which indicate that other factors are not included in this study R2 .049, SEE .935. The ANOVA of the regression indicated that the management skills was a good contributor for the selection of management model $(\mathrm{F}(4,95)=2.267, \mathrm{P}<.000)$.

Table 2. Relative Contribution of Management Skills to the selection of Management Model among

\begin{tabular}{lccccc}
\multicolumn{1}{c}{ Variables } & $\begin{array}{c}\text { Unstandardized } \\
\text { Coefficients }\end{array}$ & $\begin{array}{c}\text { Standardized } \\
\text { Coefficients } \\
\text { Beta }\end{array}$ & T & Sig. \\
& B & Std. Error & Beta & & \\
\hline (Constant) & 2.393 & .424 & & 5.638 & .000 \\
Perceptual management skills & -.078 & .101 & -.082 & -.780 & .000 \\
1Technical & -.111 & .133 & -.093 & -.834 & .000 \\
Human skills & -.195 & .114 & -.188 & -1.702 & .000 \\
Political & .341 & .121 & .324 & 2.811 & .000 \\
\hline
\end{tabular}

a. Dependent Variable: Management Model

Table 2 above present the parameter estimate (B), the Standard Error (SE), Tratio and the probability level of association between the independent variable of Managements skills (perceptual management skill, Technical, Human skills and 
Political) and the dependent variable of Management Model. The table showed that. The table showed that Political made the highest significant contribution to Management Model ( $\mathrm{B}=0.341 ; \mathrm{t}=2.811 ; \mathrm{p}<0.05)$. The second highest significant contribution was made by Human skills $(\mathrm{B}=-0.195 ; \mathrm{t}=-1.702 ; \mathrm{p}<0.05)$. Technical made the third significant contribution to Management Model $(B=-0.111 ; t=-0.834$; $\mathrm{p}<0.000$ ). Perceptual management skills made the least significant contribution to Management Model $(\mathrm{B}=-.078, \mathrm{t}=-.780, \mathrm{P}>0.000)$. This result revealed that Management skills (perceptual management skill, Technical, Human skills and Political) made a significant contribution to selection management model among sports manager. Therefore, hypothesis two is rejected which implies that Management skills contribute to the selection of Management Model.

\section{Discuss of Findings}

The effects on hypothesis one revealed that management skills (perceptual management skill, technical management skill, Human management talent and Political management skill) contribute to the selection of management model amongst sports activities managers in Kwara State. These findings corroborate Forghani (2015) submitted that sports organizations involved in sports development are no exception; they also need efficient managers and leaders. Adopting different types of management styles, managers facilitate the achievement of goals, enhance the sense of happiness and job satisfaction of the employee, extend initiatives and eventually support the internal organizational process and to attain organizational desires and therefore increase organizational effectiveness. Simulation scenarios, reflective exercises, and role-playing may also be useful to facilitate the preference of optimistic hostilities management styles (Nazari, 2017).

Robert (2019) submitted that superb administration relies upon on three basic personal skills, which have been called technical, human, and conceptual. The administrator desires adequate technical skill to accomplish the mechanics of the particular job for which he is responsible; adequate human skill in working with others to be an effective group member and to be able to build cooperative effort inside the team he leads; and adequate conceptual skill to recognize the interrelationships of the various factors involved in his situation, which will lead him to take that motion which is likely to achieve the maximum excellent for the complete organization.

The results on hypothesis two revealed that Political management skills made the highest significant contribution to the selection of Management Model $(\mathrm{B}=$ $0.341 ; \mathrm{t}=2.811 ; \mathrm{p}<0.05)$. This implies that Political Management skill played the absolute best role to sports managers in the selection of management modelas corroborated by Douglas \& Ammeter (2004) observed that manager political skill accounted for a great increment in group overall performance variance after controlling for a number of manager traits. It was also found that political skill positively helped the subordinate and supervisor rankings of managers' effectiveness (Douglas \& Ammeter, 2004) and employee perceptions of perceived support and trust (Treadway, Hochwarter, Ferris, Kacmar, Douglas, Ammeter and Buckley 2004). Harris, Kacmar, Zivnuska \& Shaw (2007) found that managers who engaged in influence management skill were rated greater favourably by their supervisor when they had excessive political skill. However, employees who had low 
political skill rankings however engaged in influence management obtained less beneficial overall performance evaluations from their supervisors.

The results on hypothesis two also revealed the second-highest significant contribution was made by Human management skills to the selection of Management Model $(\mathrm{B}=-0.195 ; \mathrm{t}=-1.702 ; \mathrm{p}<0.05)$. This implies that Human Management performed the second very best position to sports managers in the selection of management model.

The results on hypothesis two also revealed that technical management skills made the third significant contribution to the selection of Management Model $(\mathrm{B}=-$ $0.111 ; \mathrm{t}=-0.834 ; \mathrm{p}<0.000)$. This implies that Technical Management skill played the third-best possible role to sports managers in the selection of management model. Sylvia (2008) submitted that technical skill ought to incrementally predict first-tier technical managers' performance over and above what managerial skill should predict. Further submit that technical skill is predictive of subordinate perceptions of managerial performance, over and above managerial skills nonsignificant contribution. Though counterintuitive on the surface, this paradox makes sense when the results of the mediation analyses are considered. Sylvia (2008) suggested that subordinates can be productive "in spite of" their perceptions of their supervisors and, on a greater serious note; and that technical skill can add value to first-tier managerial overall performance by way of improving supervisorsubordinate relationships. When subordinates become aware of a manager to be technically skilled, they ascribe referent and professional power to him/her. Referent and expert power, in turn, translate into greater superb subordinate perceptions of managerial performance and job pleasure (Sylvia, 2008).

The results on hypothesis two, in the end, revealed that Perceptual management skills made the least significant contribution to the selection of Management Model ( $\mathrm{B}=-.078, \mathrm{t}=-.780, \mathrm{P}>0.000)$. This implies that Perceptual Management skill played the least position to sports managers in the selection of the management model but also contribute to the management model. This finding was in line with Seyedinejat, et al., (2014) who affirmed that perceptual skill refers to the ability to understand the general problems of the organization and identify the section of the organization in which a person is best fitted to work. Such knowledge allows the person to act based on the goals of the entire organization, rather than the goals and needs of one's own group.

\section{CONCLUSION}

Based on findings of this study, the researcher concluded that management skills (Political, Technical, Human and Perceptual skill) contribute to the selection of management model. This indicates the roles management skills played in the selection of management model and how it's important as it relates to several constructs such as job satisfaction, job stress and leader effectiveness.

\section{ACKNOWLEDGEMENT}

Based on the finding of the study, the following are recommended:

1. Government and stakeholder in the state should organize Seminar, Workshop and training for sports managers of the sports organizations in Kwara state them 
to have knowledge on perceptual management skills, political management skills, technical management skills, and Human management skills which is crucial to their job.

2. Sports managers in the state should address the issue of lack of management skills among sports managers through their professional association in order to improve sports managers effectiveness and efficiency in managing the affairs of sports organizations in Kwara State.

3. Sports managers should do everything possible to improve their management skills because is very crucial their overall performance or outcome as the manager to sports organization

\section{REFERENCES}

Benar N, Ramezani Nejad R, Surani M, Gohar Rostami H, Yeganehfar N. (2014) Designing a Managerial Skills Model for Chief Executive Officers (CEOs) of Professional Sports Clubs in Isfahan Province. SSR.;23(1-2):59-77.

Douglas, C. \& Ammeter, A.P. (2004). An examination of leader political skill and its effect on ratings of leader effectiveness. The Leadership Quarterly, 15, 537-550.

Fani A. A, Sheikhinejad F, Danaee-fard H, Hasanzadeh A. (2014) Investigating the Moderating Effects of Political skill and Political will on the Relationship between Perceptions of Organizational Politics and Political Behavior Case study: Water Industry of Iran. Management Research in Iran.;18(1):193-221 [Article in farsi].

Ferris, G.R., Treadway, D.C., Kolodinsky, R.W., Hochwarter, W.A., Kacmar, C.J. Douglas C. \& Frink, D.D. (2005). Development and validation of the political skill inventory. Journal of Management, 31, 126-152

Ferris, G.R., Treadway, D.C., Perrewé, P.L., Brouer, R.L. Douglas, C. \& Lux, S. (2007). Political Skill in Organizations. Journal of Management, 33, 290-320

Harris, K. J., Kacmar, K., Zivnuska, S. \& Shaw, J. D. (2007). The impact of political skill on impression management effectiveness. Journal of Applied Psychology, 92(1), 278285.

Harris, M. M., \& Schaubroeck, J. (1988). A Meta-Analysis of Self-Supervisor, Self-Peer, and PeerSupervisor Ratings. Personnel Psychology, 41(1), 43-62.

Harris, R.B., Harris, K.J., \& Harvey, P. (2007). A test of competing models of the relationships among perceptions of organizational politics, perceived organizational support, and individual outcomes. Journal ofSocial Psychology, 147(6), 631-656.

Ram, P. \& Prabhakar, G.V. (2010). Leadership styles and perceived organizational politics as predictors of work-related outcomes. European Journal of Social Sciences, 15(1), 4055.

Seyedinejat SS, Razaghi ME, Dousti M. (2014) Prioritizing managerial skills based on Katz's Theory cast study: The managers of sports and youth in Mazandaran Province. Pamukkale Journal of Sport Sciences. ;5(1):33-47.

Sylvia H (2008). The role of technical skill in perceptions of managerial performance: Journal of Management Development 27(3):275-290

Templer KJ. (2018). Dark personality, job performance ratings, and the role of political skill: An indication of why toxic people may get ahead at work. Personality and Individual Differences.;124:209-14. 
Treadway, D. C., Hochwarter, W. A., Ferris, G. R., Kacmar, C. J., Douglas, C., Ammeter, A. P. \& Buckley, M. (2004). Leader political skill and employee reactions. The Leadership Quarterly, 15, 493-513.

\section{Copyright holder:}

C(2021) Ibraheem Musa Oluwatoyin, Abdulraheem Yinusa Owolabi, Aina Gbemisola Michael

First publication right: Indonesian Journal of Sport Management

This article is licensed under:

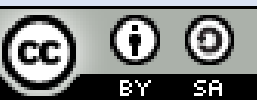

